\title{
Prevalence of Avian influenza H9N2 Virus among Wild and Domesticated Bird Species across Pakistan
}

\author{
Amna Kausar ${ }^{1,2}$, Sana Anwar', Naila Siddique ${ }^{2}$, Safia Ahmed ${ }^{1}$ and Javid Iqbal Dasti,** \\ ${ }^{1}$ Department of Microbiology, Faculty of Biological Sciences, Quaid-i-Azam University, \\ Islamabad 45320 \\ ${ }^{2}$ National Reference Lab for Poultry Diseases, Animal Sciences Institute, National \\ Agricultural Research Centre, Islamabad 45500
}

\begin{abstract}
A B S T R A C T
Aim of this study was to determine the prevalence of avian influenza virus (AIV) subtypes (AIV H9, AIV H7 and AIV H5) in non-vaccinated wild and domesticated bird species across Pakistan. During January-December 2013, in total 700 samples were collected from different species of non-vaccinated birds inhabiting diverse ecological zones of Pakistan. Altogether, 507 tissue and swab samples were screened for the presence of viral RNA by reverse transcriptase polymerase chain reaction (RT-PCR). Same samples were further processed for the isolation of virus by embryonated egg inoculation technique. Moreover, out of 507 samples, 479 serum samples were scrutinized by enzyme linked immunosorbent essay (ELISA). Sero-prevalence of AIV among different species of wild birds was as follows; peacock $(n=35 ; 14 \%)$, duck $(n=5 ; 2 \%)$, migratory water fowl $(n=3 ; 1 \%)$, pheasant $(n=2 ; 0.8 \%)$, grey leg goose $(n=1 ; 0.4 \%)$, turkey $(n=1 ; 0.4 \%)$, eagle $(n=1 ; 0.4 \%)$ and crane $(n=1 ; 0.4 \%)$, for domesticated bird species sero-prevalence was; broiler $(n=152 ; 60 \%)$, rural poultry $(n=14 ; 6 \%)$, domestic desi birds $(n=12 ; 5 \%)$, pigeons $(n=9 ; 3.6 \%)$, desi chicken $(n=9 ; 3.6 \%)$, broiler breeder $(n=3 ; 1 \%)$ and layer $(n=2 ; 0.8 \%)$. Overall sero-prevalence was $53 \%$ and average range of the hemagglutination inhibition (HI) antibody titer (MT $\log ^{2}$ ) against AIV H9 remained $7 \pm 3$. Real-time PCR results showed 8.3\% (42/507) of the samples were positive for viral matrix gene. Sub-typing was performed by specific anti-sera. PCR amplification was done by using N2 specific primers that confirmed $100 \%$ of the matrix (M) gene positive isolates as subtype H9N2. This is the first report from Pakistan that confirms prevalence of AIV H9N2 among different bird species across various regions of the country. AIV remains a pandemic threat therefore vigilance for routine AIV surveillance programs and improved vaccination strategies are highly desirable.
\end{abstract}

\begin{tabular}{|c|}
\hline Article Information \\
\hline Received 26 December 2017 \\
\hline Revised 03 March 2018 \\
\hline Accepted 18 March 2018 \\
\hline Available online 28 May 2018 \\
\hline Authors' Contribution \\
\hline $\begin{array}{l}\text { NS designed the experiments. AK } \\
\text { performed the experiments. JID, Sana } \\
\text { A and Safia A analyzed the data. JID } \\
\text { wrote the manuscript. }\end{array}$ \\
\hline Key words \\
\hline $\begin{array}{l}\text { Avian influenza (IV), AIV H9N2, HI } \\
\text { antibody, RT-PCR, Pakistan. }\end{array}$ \\
\hline
\end{tabular}

\section{INTRODUCTION}

A vian influenza (AI) is highly transmissible viral infection caused by different subtypes of influenza viruses. Based on the antigenic differences of the structural proteins, such as nucleoprotein (NP) and matrix protein (M1), virus is classified into three types; $\mathrm{A}, \mathrm{B}$ and $\mathrm{C}$. However, only type A influenza virus is further classified into different subtypes which are based on the antigenicity of two transmembrane glycoproteins termed, hemagglutinin $(\mathrm{H})$ and neuraminidase $(\mathrm{N})$. So far, amongst aquatic wild birds, in total sixteen $\mathrm{H}$ (H1H16) and nine N(N1-N9) serotypes have been reported (Adams et al., 2016; Gonzalez-Reiche et al., 2016). Avian influenza virus (AIV) being highly species-specific mainly infects birds. Wild aquatic birds like geese, waterfowl, shorebirds and wild ducks serve as the natural

\footnotetext{
* Corresponding author: iqbal78@hushmail.com 0030-9923/2018/0004-1347 \$ 9.00/0

Copyright 2018 Zoological Society of Pakistan
}

reservoirs for these viruses. Due to mutagenic nature of AIV, they pose consistent threat and may cross specie specific barriers (Sarwar et al., 2013). Since 1995-2003, in Pakistan five major AIV epidemics have been associated with circulating subtypes of avian influenza such as H5, H7 and H9. During these years, due to a highly pathogenic avian influenza (HPAI) subtype H7N3 loss of 3.2 million birds was recorded (Sarwar et al., 2013).

The first outbreak of AIV H9N2 in poultry was reported in 1998 that showed similarities with the AIV subtypes circulating in Hong Kong (Khalil et al., 2017). The subtype H9N2 usually causes mild morbidity but exceptionally higher morbidity was also reported in China during the years; 1995-2002 (Choi et al., 2004). Over the years, H9N2 infections have been associated with 5-30\% mortality rates among poultry. Moreover, in China, swine infection due to H9N2 was reported recently (Chan et al., 2017; Sarwar et al., 2013). Likewise, laboratory confirmed cases of H9N2 among humans have been reported previously (years; 1997, 2005, 2008 and 2013). Notably, first human case of H9N2 was reported among 
children, however later on prevalence of the virus was also confirmed among adults residing in Hong Kong and Mainland China (Chan et al., 2017; Wu et al., 2017).

Taken together, since, 1997 in different countries including Southern China, Thailand, Vietnam and Indonesia cases of AI subtypes H9N2 and H5N1 have been encountered repeatedly (Mukhtar et al., 2007; Sarwar et al., 2013; Xu et al., 1999). For the identification of AIV, various conventional diagnostic tests have been available such as hemagglutination inhibition (HI) and reverse transcriptase polymerase chain reaction (RTPCR) (Vemula et al., 2016). Similarly, isolation of AIV through chicken embryos is an important method (Sarwar et al., 2013). In the current study, we used conventional and molecular diagnostic tests, in combination with viral culture, for the precise identification of AIV among various specimens collected from birds. This study determines the prevalence of AIV among different non-vaccinated bird species belonging to the different ecological zones and natural habitats of Pakistan and provides a comparison of different methods for the identification of AIV.

\section{MATERIALS AND METHODS}

\section{Study area and period}

The samples from various non-vaccinated bird species suspected for an avian influenza virus infection were collected from different ecological zones of Pakistan including Khyber Pakhtunkhwa (KPK), Punjab, Baluchistan, Sindh and Islamabad capital territory (ICT). Study period lasted from January to December 2013.

\section{Target bird population}

Random samples of different bird species ranging from wild domestic fancy birds (parrots, cocktail, dove, duck, eagle, falcon, fancy, parakeet, partridges, pea fowl, peacock, pheasant, pigeon and turkey), wild migratory birds (crane, geese, jungle fowl and water fowl), backyard poultry (rural, golden and desi chickens) and commercial poultry (layer, breeder and broiler) were collected and scrutinized.

\section{Sample size}

In total, 700 samples were collected. The proportions of the samples from different regions were as follows; KPK, n=201 (29\%); Baluchistan, n=196 (28\%); Punjab, $\mathrm{n}=61(9 \%)$; Sindh, $\mathrm{n}=202(28 \%)$ and ICT, $\mathrm{n}=40(6 \%)$. Though the samples were collected throughout the year, majority of the samples were collected during winter season (Dec-Feb, $n=237 / 700$ ), followed by summer (JunAug, $n=180 / 700$ ), spring (March-May, $n=159 / 700$ ) and
Autumn (Sep-Nov, $n=124 / 700$ ). It has been reported that most of the outbreaks of HPAI occur during winter season (Biswas et al., 2014).

\section{Sample collection and processing}

Three types of samples were included in this study; (a) morbid organ samples, which included trachea, lungs, spleen, tonsils, pancreas and kidney all collected from dead birds; (b) cloacal and tracheal swab samples collected from various bird species having signs and symptoms of influenza like disease, which were transported separately by using sterile viral transport media; (c) serum samples were collected from suspected live birds. For this, whole blood sample was drawn aseptically from the wings or jugular veins of living birds. Each sample was immediately transferred to the sterile tube. After clotting at an ambient temperature, for serum separation blood samples were centrifuged at $10,000 \mathrm{rpm}(30 \mathrm{~min}$ at $4 \mathrm{oC})$. Finally, the serum was transferred to cryovials and stored at $-20^{\circ} \mathrm{C}$.

\section{Serological evaluation}

Sero-prevalence was determined by by enzyme- linked immunosorbent assay (ELISA) and Hemagglutination Inhibition (HI) test. ELISA was performed by using IDEXX AIV antibody detection test kit. To measure the titers, Hemagglutination (HA) test was performed according to the procedure recommended by OIE guideline manual 2012. For this purpose, $0.5 \%$ chicken RBCs were used. The 4HA unit (4HAU) and end point titers for H5, $\mathrm{H} 7$ and H9 were calculated as described earlier (Allan et al., 1978; Gugong et al., 2012). The HA titers were reciprocal of the highest dilution of serum showing complete inhibition of 4HA unit of the antigen. In the last step HI assay was performed for subtyping of AIV according to the procedure described in OIE guidelines manual of 2012 (Allan et al., 1978; Cheema et al., 2011; Gugong et al., 2012).

\section{Viral isolation}

The tissue material was diluted and blended with stomacher machine for $60 \mathrm{sec}$. The tissue homogenate was centrifuged and supernatant was filtered through $0.2 \mu \mathrm{m}$ filter, prior to the inoculation. By using viral inoculation (VI) technique sample from each bird was inoculated in 9-days old pathogen free embryonated chicken eggs (ECEs). The allantoic fluid from each surviving egg was tested for the presence of hemagglutinating agent by using HA test and was further confirmed through virus neutralization (hemagglutination inhibition) test. The samples with no HA was considered negative (Cheema et al., 2011; Gugong et al., 2012). 
Table I.- Seasonal distribution of AIV ELISA positive serum samples across different provinces of Pakistan during the year 2013.

\begin{tabular}{lccccc}
\hline & $\begin{array}{c}\text { Spring (Mar-May) } \\
\mathbf{n ~ ( \% )}\end{array}$ & $\begin{array}{c}\text { Summer (Jun-Aug) } \\
\mathbf{n ~ ( \% )}\end{array}$ & $\begin{array}{c}\text { Autumn (Sept-Nov) } \\
\mathbf{n}(\mathbf{\%})\end{array}$ & $\begin{array}{c}\text { Winter (Dec-Jan) } \\
\mathbf{n}(\mathbf{\%})\end{array}$ & $\begin{array}{c}\text { Total } \\
\mathbf{n = 2 5 2}\end{array}$ \\
\hline Sindh & $6(2.9 \%)$ & $56(22 \%)$ & $25(10 \%)$ & $34(13.4 \%)$ & $48 \%$ \\
Balochistan & $33(13.1 \%)$ & $19(7.5 \%)$ & $0(0 \%)$ & $13(5.2 \%)$ & $26 \%$ \\
KPK & $46(18.2 \%)$ & $5(2 \%)$ & $0(0 \%)$ & $9(4 \%)$ & $24 \%$ \\
Punjab & $3(1.2 \%)$ & $1(0.4 \%)$ & $1(0.4 \%)$ & $1(0.4 \%)$ & $2.4 \%$ \\
Total & $35 \%$ & $32 \%$ & $10 \%$ & $23 \%$ & $\mathbf{n}=\mathbf{2 5 2}$ \\
\hline
\end{tabular}

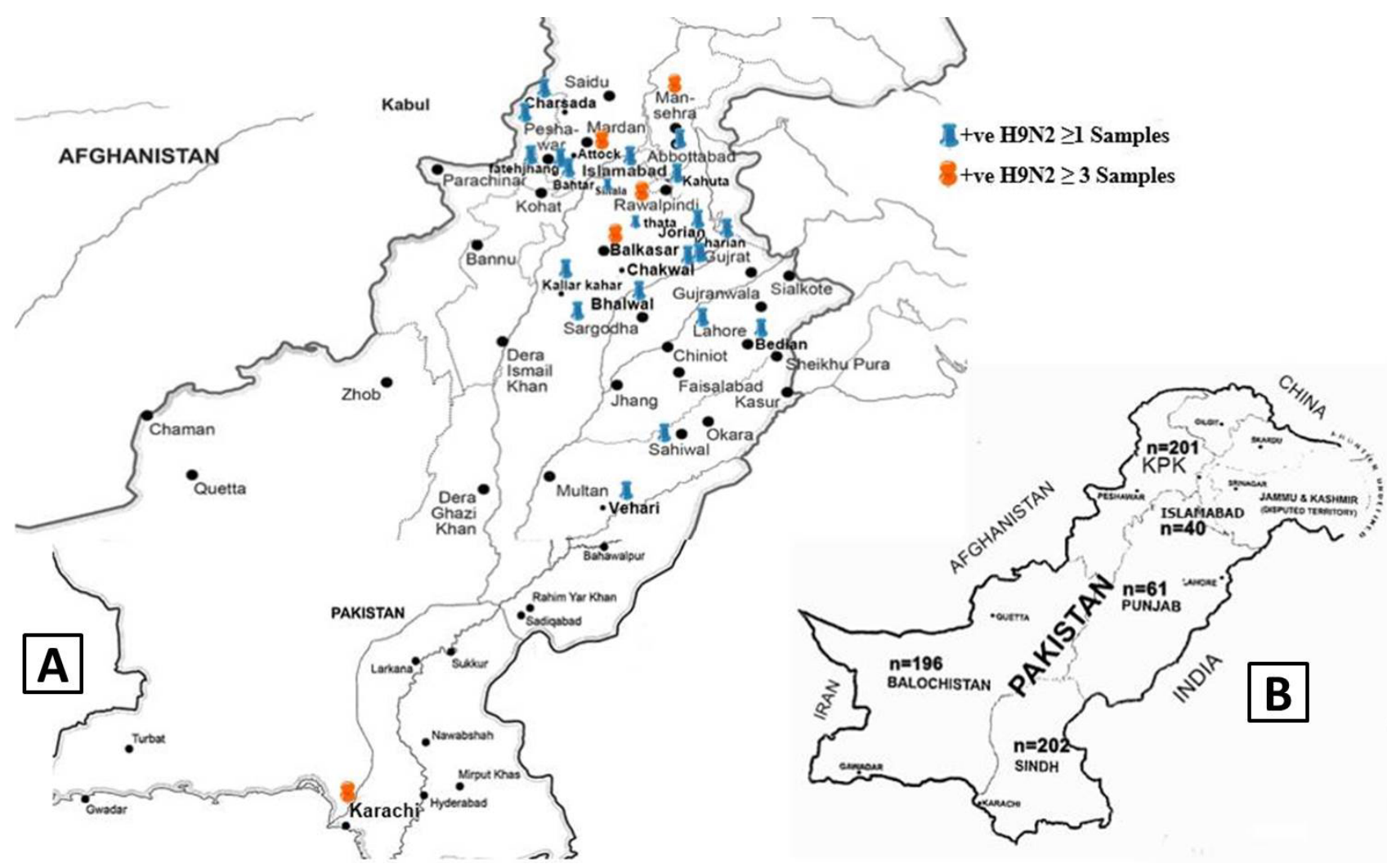

Fig. 1. Areas and occurrence (A) and sampling (B) of H9N2 among different bird species across Pakistan in year 2013.

\section{Subtype confirmation of AIV}

The allantoic fluid (AF) indicating positive HA activity were typed using specific reference anti sera against various types. The result was recorded after incubation of each microtiter plate for $20-30 \mathrm{~min}$ at $37^{\circ} \mathrm{C}$. Positive neutralization with corresponding anti-sera was considered viral HA subtype.

\section{Molecular diagnosis by RT-PCR}

The AIV RNA was extracted from positive samples by using commercially available RNA extraction kit (BioNeer, South Korea, Cat. No. K 3033) according to the manufacturer guidelines. Extracted AIV RNA samples were screened for Matrix (M) gene (specific for all AIV) by using reverse transcriptase polymerase chain reaction (RTPCR) kit (Invitrogen SuperScript ${ }^{\mathrm{TM}}$ one step RT-PCR with Platinum Taq Cat. No. 10928-042) as per manufacturers guidelines. The M-gene positive samples were further tested for the AIV subtypes by using AIV H9, H7 and H5 specific primers (Sarwar et al., 2013; Seifi et al., 2010). For the detection of N-type isolates all the influenza $\mathrm{H}$ type positive samples were screened for N2 by RT-PCR using specific primers. The amplified products were analyzed on agarose gel. 


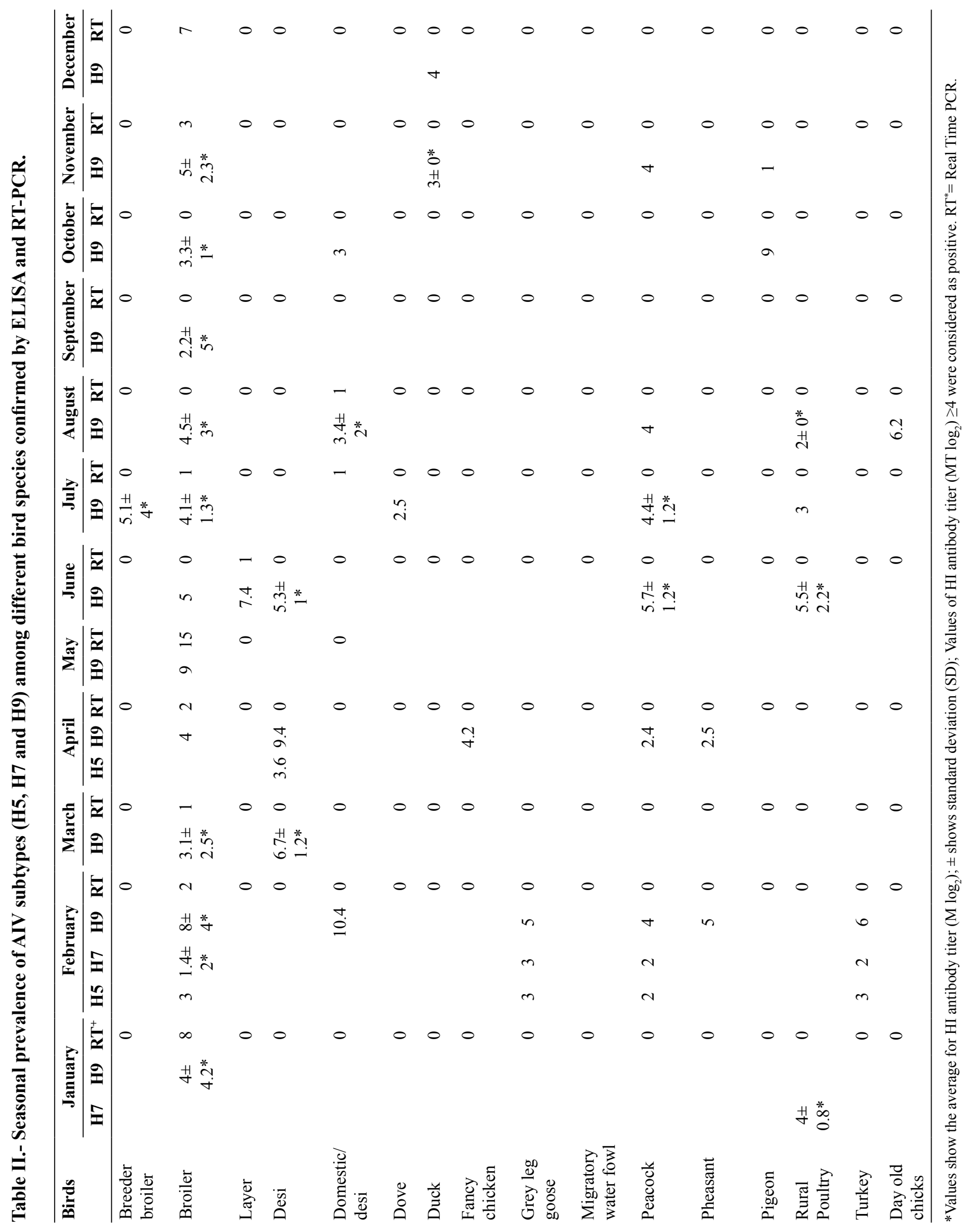




\section{RESULTS}

Sero-prevalence of antibodies against AIV

Total of 479 serum samples were tested for the seroprevalence of antibodies against AIV and 53\% $(n=252)$ were positive by ELISA. Maximum numbers of the positive samples for AIV antibodies were detected in the month of May $(n=43 ; 17 \%)$, followed by August $(n=41$; $16 \%)$. Seasonal prevalence of the virus was higher in spring $(n=88 ; 35 \%)$, followed by summer $(n=81 ; 32 \%)$, winter $(n=57 ; 23 \%)$ and autumn $(n=26 ; 10 \%)$. Overall, sero-prevalence was highest among the samples recovered from Sindh $(\mathrm{n}=121 ; 48 \%)$, followed by Baluchistan $(\mathrm{n}=65$; $26 \%), \operatorname{KPK}(n=60 ; 24 \%)$ and Punjab $(n=6 ; 2.4 \%)$ (Table I, Supplementary Table I \& II). Overall sero-prevalence among different bird species was as follows; broiler $(\mathrm{n}=152$; $60.3 \%)$, peacock $(n=35 ; 14 \%)$, rural poultry $(n=14 ; 6 \%)$, domestic desi birds $(n=12 ; 5 \%)$, pigeons $(n=9 ; 3.6 \%)$, desi chicken $(\mathrm{n}=9 ; 3.6 \%)$, duck $(\mathrm{n}=5 ; 2 \%)$, migratory water fowl $(\mathrm{n}=3 ; 1.2 \%)$, broiler breeder $(\mathrm{n}=3 ; 1.2 \%)$, layer $(\mathrm{n}=2 ; 0.8 \%)$, pheasant $(\mathrm{n}=2 ; 0.8)$, greylag goose $(\mathrm{n}=1 ; 0.4 \%)$, turkey $(n=1 ; 0.4 \%)$, eagle $(n=1 ; 0.4 \%)$ and crane $(n=1 ; 0.4 \%)$.

\section{Isolation and identification of AIV}

By using RT-PCR $n=42(8.3 \%)$ of 507 samples collected from different regions were positive for matrix genes (Fig. 1). Matrix gene positive sample were further processed for subtyping by using PCR. All the samples $(n=42)$ were positive for H9 subtype of the virus. While none of the samples were positive for subtype H5 and H7. The H9 confirmed samples were tested for N2 type, and all were classified as AIV subtype "H9N2". By using PCR maximum prevalence of the virus was recorded in the Punjab province $(n=29 ; 69 \%)$ followed by KPK $(\mathrm{n}=8 ; 19 \%)$ and Sindh $(\mathrm{n}=5 ; 12 \%)$, whereas no AIV positive sample was reported from Baluchistan (Table III).

Table III.- Month-wise distribution of AIV H9N2 in different cities of Pakistan during the year 2013.

\begin{tabular}{|c|c|c|c|c|c|c|c|c|c|c|c|c|c|}
\hline City & $\begin{array}{l}\text { Jan } \\
n=8\end{array}$ & $\begin{array}{l}\text { Feb } \\
n=2\end{array}$ & $\begin{array}{c}\text { Mar } \\
n=1\end{array}$ & $\begin{array}{l}\text { Apr } \\
\mathrm{n}=2\end{array}$ & $\begin{array}{l}\text { May } \\
\mathrm{n}=15\end{array}$ & $\begin{array}{l}\text { Jun } \\
n=1\end{array}$ & $\begin{array}{l}\text { Jul } \\
n=2\end{array}$ & $\begin{array}{l}\text { Aug } \\
n=1\end{array}$ & $\begin{array}{l}\text { Sep } \\
n=0\end{array}$ & $\begin{array}{l}\text { Oct } \\
\text { n=0 }\end{array}$ & $\begin{array}{l}\text { Nov } \\
n=3\end{array}$ & $\begin{array}{l}\text { Dec } \\
n=7\end{array}$ & $\begin{array}{l}\text { Total } \\
\mathrm{n}=42\end{array}$ \\
\hline Abbottabad & $0 \%$ & $0 \%$ & $0 \%$ & $0 \%$ & $0 \%$ & $0 \%$ & $0 \%$ & $100 \%$ & $0 \%$ & $0 \%$ & $0 \%$ & $14.2 \%$ & 2 \\
\hline Attock & $0 \%$ & $0 \%$ & $0 \%$ & $50 \%$ & $13.3 \%$ & $0 \%$ & $0 \%$ & $0 \%$ & $0 \%$ & $0 \%$ & $0 \%$ & $0 \%$ & 3 \\
\hline Bahtar More & $0 \%$ & $0 \%$ & $0 \%$ & $0 \%$ & $0 \%$ & $0 \%$ & $0 \%$ & $0 \%$ & $0 \%$ & $0 \%$ & $0 \%$ & $14.2 \%$ & 1 \\
\hline Balkasar & $0 \%$ & $0 \%$ & $0 \%$ & $0 \%$ & $20 \% *$ & $0 \%$ & $0 \%$ & $0 \%$ & $0 \%$ & $0 \%$ & $0 \%$ & $0 \%$ & 3 \\
\hline Bedian & $0 \%$ & $0 \%$ & $0 \%$ & $0 \%$ & $6.7 \%$ & $0 \%$ & $0 \%$ & $0 \%$ & $0 \%$ & $0 \%$ & $0 \%$ & $0 \%$ & 1 \\
\hline Bhalwal & $0 \%$ & $0 \%$ & $0 \%$ & $0 \%$ & $6.7 \%$ & $0 \%$ & $0 \%$ & $0 \%$ & $0 \%$ & $0 \%$ & $0 \%$ & $0 \%$ & 1 \\
\hline Chakwal & $0 \%$ & $50 \%$ & $0 \%$ & $50 \%$ & $0 \%$ & $0 \%$ & $0 \%$ & $0 \%$ & $0 \%$ & $0 \%$ & $0 \%$ & $0 \%$ & 2 \\
\hline Charsada & $12.5 \%$ & $0 \%$ & $0 \%$ & $0 \%$ & $0 \%$ & $0 \%$ & $0 \%$ & $0 \%$ & $0 \%$ & $0 \%$ & $0 \%$ & $0 \%$ & 1 \\
\hline Fatejang & $0 \%$ & $0 \%$ & $0 \%$ & $0 \%$ & $0 \%$ & $0 \%$ & $0 \%$ & $0 \%$ & $0 \%$ & $0 \%$ & $0 \%$ & $28.6 \%$ & 2 \\
\hline Islamabad & $12.5 \% *$ & $0 \%$ & $0 \%$ & $0 \%$ & $0 \%$ & $0 \%$ & $0 \%$ & $0 \%$ & $0 \%$ & $0 \%$ & $0 \%$ & $0 \%$ & 1 \\
\hline Jorrian & $0 \%$ & $0 \%$ & $0 \%$ & $0 \%$ & $6.7 \%$ & $0 \%$ & $0 \%$ & $0 \%$ & $0 \%$ & $0 \%$ & $0 \%$ & $0 \%$ & 1 \\
\hline Kahuta & $0 \%$ & $0 \%$ & $0 \%$ & $0 \%$ & $6.7 \%$ & $0 \%$ & $0 \%$ & $0 \%$ & $0 \%$ & $0 \%$ & $0 \%$ & $0 \%$ & 1 \\
\hline Kallarkahar & $12.5 \% *$ & $0 \%$ & $0 \%$ & $0 \%$ & $0 \%$ & $0 \%$ & $0 \%$ & $0 \%$ & $0 \%$ & $0 \%$ & $0 \%$ & $0 \%$ & 1 \\
\hline Karachi & $0 \%$ & $50 \%$ & $100 \% *$ & $0 \%$ & $0 \%$ & $0 \%$ & $50 \%$ & $0 \%$ & $0 \%$ & $0 \%$ & $33.3 \%$ & $0 \%$ & 4 \\
\hline Kharian & $0 \%$ & $0 \%$ & $0 \%$ & $0 \%$ & $6.7 \%$ & $0 \%$ & $0 \%$ & $0 \%$ & $0 \%$ & $0 \%$ & $0 \%$ & $0 \%$ & 1 \\
\hline Lahore & $12.5 \%$ & $0 \%$ & $0 \%$ & $0 \%$ & $0 \%$ & $0 \%$ & $0 \%$ & $0 \%$ & $0 \%$ & $0 \%$ & $0 \%$ & $0 \%$ & 1 \\
\hline Mandibahudin & $0 \%$ & $0 \%$ & $0 \%$ & $0 \%$ & $6.7 \% *$ & $0 \%$ & $0 \%$ & $0 \%$ & $0 \%$ & $0 \%$ & $0 \%$ & $14.2 \%$ & 2 \\
\hline Mansehra & $0 \%$ & $0 \%$ & $0 \%$ & $0 \%$ & $13.3 \% *$ & $0 \%$ & $50 \%$ & $0 \%$ & $0 \%$ & $0 \%$ & $0 \%$ & $14.2 \%$ & 4 \\
\hline Peshwar & $0 \%$ & $0 \%$ & $0 \%$ & $0 \%$ & $6.7 \%$ & $0 \%$ & $0 \%$ & $0 \%$ & $0 \%$ & $0 \%$ & $0 \%$ & $0 \%$ & 1 \\
\hline Rawalpindi & $25 \% *$ & $0 \%$ & $0 \%$ & $0 \%$ & $0 \%$ & $100 \%$ & $0 \%$ & $0 \%$ & $0 \%$ & $0 \%$ & $0 \%$ & $0 \%$ & 3 \\
\hline Sahiwal & $0 \%$ & $0 \%$ & $0 \%$ & $0 \%$ & $0 \%$ & $0 \%$ & $0 \%$ & $0 \%$ & $0 \%$ & $0 \%$ & $0 \%$ & $14.2 \%$ & 1 \\
\hline Sargodha & $0 \%$ & $0 \%$ & $0 \%$ & $0 \%$ & $6.7 \%$ & $0 \%$ & $0 \%$ & $0 \%$ & $0 \%$ & $0 \%$ & $0 \%$ & $0 \%$ & 1 \\
\hline Sihala & $12.5 \%$ & $0 \%$ & $0 \%$ & $0 \%$ & $0 \%$ & $0 \%$ & $0 \%$ & $0 \%$ & $0 \%$ & $0 \%$ & $0 \%$ & $0 \%$ & 1 \\
\hline Thatha & $0 \%$ & $0 \%$ & $0 \%$ & $0 \%$ & $0 \%$ & $0 \%$ & $0 \%$ & $0 \%$ & $0 \%$ & $0 \%$ & $33.3 \%$ & $0 \%$ & 1 \\
\hline Vehari & $12.5 \% *$ & $0 \%$ & $0 \%$ & $0 \%$ & $0 \%$ & $0 \%$ & $0 \%$ & $0 \%$ & $0 \%$ & $0 \%$ & $0 \%$ & $0 \%$ & 1 \\
\hline Wahcantt & $0 \%$ & $0 \%$ & $0 \%$ & $0 \%$ & $0 \%$ & $0 \%$ & $0 \%$ & $0 \%$ & $0 \%$ & $0 \%$ & $33.3 \%$ & $0 \%$ & 1 \\
\hline
\end{tabular}

*Shown are the distribution of RT-PCR + ve samples across different cities of Pakistan, which were confirmed negative by embryonated egg inoculation method. 
The distribution of AIV among different non-vaccinated bird species remained as follow; broilers $(n=39 ; 93 \%)$, desi poultry $(n=2 ; 4.7 \%)$ and 3 day old layer $(n=1 ; 2.3 \%)$. Furthermore, $6.5 \%$ of the AIV H9N2 samples were confirmed by viral culture isolation (also positive for HA antibody). Month wise prevalence of the AIV H9N2 was as follows (May, $n=15 ; 36 \%$ ), followed by (January, $n=8$; $19 \%$ ) and (December, $n=7 ; 17 \%$ ) and is shown (Table IV, Supplementary Table II). Overall, maximal seasonal prevalence of the virus was recorded during spring season and minimal during the autumn.

Table IV.- Prevalence of AIV H9N2 confirmed by RTPCR during the different months of 2013.

\begin{tabular}{lclc}
\hline Month & $\begin{array}{c}\text { n (\%) of AIV } \\
\text { H9N2 }\end{array}$ & Month & $\begin{array}{c}\text { n (\%) of AIV } \\
\text { H9N2 }\end{array}$ \\
\hline January & $08(19 \%)$ & July & $02(5 \%)$ \\
February & $02(5 \%)$ & August & $01(2 \%)$ \\
March & $01(2 \%)$ & September & $0(0 \%)$ \\
April & $02(5 \%)$ & October & $0(0 \%)$ \\
May & $15(36 \%)$ & November & $03(7 \%)$ \\
June & $01(2 \%)$ & December & $07(17 \%)$ \\
Total & & $\mathbf{4 2}$ & \\
\hline
\end{tabular}

\section{DISCUSSION}

Over the last few decades, AIV accounted for significant losses to the domestic poultry across the globe. The infections caused by multiple AIV serotypes produce asymptomatic to fatal disease amongst pigs, horses, wild and domestic birds. The wild aquatic birds like geese, shore birds, waterfowl and wild ducks are considered the natural reservoir for AIV (Bergervoet et al., 2017). Since 1995, Pakistan has experienced several AI outbreaks of AIV serotypes including H7N3, H9N2 and H5N1 were reported from Pakistan (Ayaz et al., 2017; Khalil et al., 2017). These multiple episodes of infections with LPAI (low pathogenic) and HPAI (high pathogenic) outbreaks caused massive economic losses in the poultry industry of Pakistan and subsequently directed the initiation of AIV surveillance throughout the country. The present study was conducted to determine the sero-prevalence of AIV subtypes AIV H5, AIV H7, AIV H9. Isolation and identification of these viral subtypes in vrious non vaccinated bird species was performed throughout the year 2013.

It is the first large scale study conducted in Pakistan which reports prevalence of $\mathrm{H} 9 \mathrm{~N} 2$ among wild birds, after the year 2005 AIV surveillance study of Khawaja et al. (2005). In our study, out of total 479 serum samples, only
53\% $(\mathrm{n}=252)$ were positive for AIV antibodies by using ELISA. Previously varying sero-prevalence of AIV H9 has been reported from other countries, for example from Nigeria 52.9\%, U.S (Texas) 57\%, South Korea 77.2\% and Egypt 61.6\% (Aiki-Raji et al., 2015; Hassan et al., 2016; Lee et al., 2017; Wang et al., 2014; Wong et al., 2016). A recent study from Pakistan by Akhter et al. (2017) reported comparable sero-prevalence $(60 \%)$ for H9N2 but only among commercial layers. According to Arif et al. (2015) AIV sero-prevalence of $14 \%$ was recorded in broilers, which is lower in comparison to the findings of current study. In the present study, majority of AIV H9N2 samples were recovered from broilers, $n=39$ (92\%). However, other study reported higher prevalence of H9N2 in layers (Usman et al., 2017). Variables such as sample size and geographical zones, weather conditions, immunological factors may influence the outcomes in different studies.

In this study by egg inoculation method 33(6.5\%) samples were positive for AIV which were further confirmed as H9N2 by HA (Hemagglutination) test. Molecular detection of AIV using RT-PCR method revealed that $42(8.3 \%)$ samples were positive for M-gene (common in all AIV subtypes). By using specific primers for AIV H9 and N2, M-gene positive samples $(n=42)$ were confirmed as AIV H9N2 subtype. Likewise, samples positive by egg inoculation method $n=33$ were also confirmed as H9N2 by PCR. However, observed difference in the viral detection of two methods endorses the sensitivity of PCR, in comparison to the traditional egg inoculation technique. Moreover, viral titer in the allontoic fluid of embryonated egg may not suffice a detection by HA/antigen titration assay, whereas PCR being more sensitive can amplify minute quantities of viral RNA. Therefore, for the largescale epidemiological surveillance of AIV, PCR can be the method of choice. Moreover, because of its sensitivity and ease of performance, PCR has advantage over in-vivo inoculation method which is labor intensive.

Overall, this study indicates greater AIV seroprevalence $(53 \%)$ and a higher $\mathrm{HI}$ antibody titer against AIV H9 when compared to actual viral load $(8.3 \%$ via RT-PCR) obtained from birds. These observations endorse a persistent exposure of wild birds to influenza virus leading to the gain of natural immunity against AIV. In the current study, it was observed that maximum numbers of AIV H9N2 occurrence was in spring season $(n=18,43 \%)$ followed by winters $(n=14,40 \%)$ (Table IV). However, in the present study number of samples received from different ecological zones of Pakistan may not suffice to conclude its true prevalence in terms of ecological factors. Yet, it was evident that prevalence of AIV H9N2 in nonvaccinated birds was higher among the samples obtained from birds living near large water reservoirs (like dams or 
lakes etc.). Another limitation of this study is lack of viral genome sequence analysis that would help to elucidate eco-epidemiology and spread of AIV.

\section{CONCLUSION}

Conclusively, this study confirms prevalence of AIV H9N2 among various bird species across Pakistan. Since AIV poses, persistent threat to the poultry industry across various regions including Asian pacific and SouthEast Asia regions national AI surveillance programs must include farmer's awareness about vaccines, improvements in biosecurity measures, monitoring interactions among wild life, migratory birds and poultry. Moreover, vigilance regarding prevalence of different subtypes of AIV, which may pose risk for human infections, should be given high priority.

\section{ACKNOWLEDGMENT}

We truly appreciate the staff of National Reference Lab for Poultry Diseases, Animal Sciences Institute of National Agricultural Research Centre (NARC), Islamabad for granting us the lab facilities.

\section{Supplementary material}

There is supplementary material associated with this article. Access the material online at: http://dx.doi. org/10.17582/journal.pjz/2018.50.4.1347.1354

\section{Statement of conflict of interest}

The authors have declared that there is no conflict of interests.

\section{REFERENCES}

Adams, M.J., Lefkowitz, E.J., King, A.M., Harrach, B., Harrison, R.L., Knowles, N.J., Kropinski, A.M., Krupovic, M., Kuhn, J.H. and Mushegian, A.R., 2016. Ratification vote on taxonomic proposals to the International Committee on Taxonomy of Viruses. Arch. Virol., 161: 2921-2949. https://doi. org/10.1007/s00705-016-2977-6

Aiki-Raji, C.O., Adebiyi, A.I., Agbajelola, V.I., Adetunji, S.A., Lameed, Q., Adesina, M., Adekanye, G., Omidokun, F., Fagbohun, O. and Oluwayelu, D.O., 2015. Surveillance for low pathogenic avian influenza viruses in live-bird markets in Oyo and Ogun States, Nigeria. Asian. Pac. J. trop. Dis., 5: 369-373.

Akhter, H., Aslam, B., Shahzad, N., Farooq, T., Umer, M. and Rasool, M.H., 2017. Molecular and serological detection of avian influenza H9N2 virus in asymptomatic commercial layers in Faisalabad district, Punjab. Pakistan J. Zool., 49: 395-398.

Allan, W.H., Lancaster, J.E. and Toth, B., 1978. Newcastle disease vaccines, their production and use. Food and Agriculture Organization of the United Nations.

Arif, M., Rind, R.U., Shah, M.G., Nisha, A.R., Umer, M., Kaka, U., Zaman, A., Tariq, M., Rehman, S.A., Hasan, S.M. and Khan M.S., 2015. Seroprevalence of avian influenza in broilers of district Quetta, Balochistan, Pakistan. J. Chem. Pharm. Res., 7: 1378-1384.

Ayaz, M., Abbas, M.A., Amin, Y., Ali, Z., Siddique, N. and Naeem, K., 2017. Prevalence of H9N2 avian influenza viruses in Hazara Region of Pakistan. Pakistan. J. Zool., 49:1503-1503.

Bergervoet, S., Heutink, R., Pritz-Verschuren, S., Poen, M., Bouwstra, R., Fouchier, R. and Beerens, N., 2017. A41 Diversity and evolution of avian influenza (AI) viruses in poultry and wild birds. Virus Evolut., 3(Suppl-1): https://doi.org/10.1093/ ve/vew036.040

Biswas, P.K., Islam, M.Z., Debnath, N.C. and Yamage, M., 2014. Modeling and roles of meteorological factors in outbreaks of highly pathogenic avian influenza H5N1. PLoS One, 9: e98471. https://doi. org/10.1371/journal.pone.0098471

Chan, R.W., Chan, L.L., Mok, C.K., Lai, J., Tao, K.P., Obadan, A., Chan, C.W.M., Perez, D.R., Peiris, M.J.S. and Nicholls, J.M., 2017. Replication of H9 influenza viruses in the human ex vivo respiratory tract, and the influence of neuraminidase on virus release. Scient. Rep., 7: 6208. https://doi. org/10.1038/s41598-017-05853-5

Cheema, B.F., Siddique, M., Sharif, A., Mansoor, M.K. and Iqbal, Z., 2011. Seroprevalence of avian influenza in broiler flocks in district Gujranwala (Pakistan). Int. J. Agric. Biol., 13: 850-856.

Choi, Y., Ozaki, H., Webby, R., Webster, R., Peiris, J., Poon, L., Butt, C., Leung, Y.H.C. and Guan, Y., 2004. Continuing evolution of H9N2 influenza viruses in Southeastern China. J. Virol., 78: 86098614. https://doi.org/10.1128/JVI.78.16.86098614.2004

Gonzalez-Reiche, A.S., Müller, M.L., Ortiz, L., Cordón-Rosales, C. and Perez, D.R., 2016. Prevalence and diversity of low pathogenicity avian influenza viruses in wild birds in Guatemala, 2010-2013. Avian Dis., 60: 359-364. https://doi. org/10.1637/11130-050715-Reg

Gugong, V.T., Ajogi, I., Junaidu, K., Okolocha, E.C., 
Ngbede, E.O., Abraham, M.N. and Hambolu, S.E., 2012. Avian influenza in village chickens, its awareness and presence of potential risk practices among rural dwellers. Asian. Pac. J. trop. Dis., 2: 282-285.

Hassan, K.E., Shany, S.A., Ali, A., Dahshan, A.H.M., El-Sawah, A.A. and El-Kady, M.F., 2016. Prevalence of avian respiratory viruses in broiler flocks in Egypt. Poult. Sci., 95: 1271-1280. https:// doi.org/10.3382/ps/pew068

Khalil, A.T., Ali, M., Tanveer, F., Ovais, M., Idrees, M., Shinwari, Z.K. and Hollenbeck, J.E., 2017. Emerging viral infections in Pakistan: Issues, concerns, and future prospects. Hlth. Secur, 15: 268-281. https://doi.org/10.1089/hs.2016.0072

Khawaja, J., Naeem, K., Ahmed, Z. and Ahmad, S., 2005. Surveillance of avian influenza viruses in wild birds in areas adjacent to epicenter of an outbreak in federal capital territory of Pakistan. Int. J. Poult. Sci, 4: 39-43. https://doi.org/10.3923/ ijps.2005.39.43

Lee, E.K., Kang, H.M., Song, B.M., Lee, Y.N., Heo, G.B., Lee, H.S., Lee, L.J. and Kim, J.H., 2017. Surveillance of avian influenza viruses in South Korea between 2012 and 2014. Virol. J., 14: 54. https://doi.org/10.1186/s12985-017-0711-y

Mukhtar, M.M., Rasool, S.T., Song, D., Zhu, C., Hao, Q., Zhu, Y. and Wu, J., 2007. Origin of highly pathogenic $\mathrm{H} 5 \mathrm{~N} 1$ avian influenza virus in China and genetic characterization of donor and recipient viruses. J. Gen. Virol., 88: 3094-3099. https://doi. org/10.1099/vir.0.83129-0

Sarwar, M., Muhammad, K., Rabbani, M., Younus, M., Sarwar, N., Ali, M. and Ahad, A., 2013. Prevalence of avian influenza viruses in live bird markets of Lahore. J. Anim. Pl. Sci., 23: 388-392.
Seifi, S., Asasi, K. and Mohammadi, A., 2010. Natural co-infection caused by avian influenza H9 subtype and infectious bronchitis viruses in broiler chicken farms. Vet. Arhiv., 80: 269-281.

Usman, M., Sarwar, F., Umar, S., Subhan, S., Sohail, M., Younus, M. and Shah, M., 2017. A clinical survey of viral respiratory diseases of commercial poultry in Pakistan. J. Anim. Pl. Sci.,27: 2086-2089.

Vemula, S.V., Zhao, J., Liu, J., Wang, X., Biswas, S. and Hewlett, I., 2016. Current approaches for diagnosis of influenza virus infections in humans. Viruses, 8: 96. https://doi.org/10.3390/v8040096

Wang, G., Zhang, T., Li, X., Jiang, Z., Jiang, Q., Chen, Q., Tu, X., Chen, Z., Chang, J., Li, L. and Xu, B., 2014. Serological evidence of H7, H5 and $\mathrm{H} 9$ avian influenza virus co-infection among herons in a city park in Jiangxi, China. Scient. Rep., 4: 6345. https://doi.org/10.1038/srep06345

Wong, J.K., Wilcox, B.R., Fojtik, A., Poulson, R.L. and Stallknecht, D.E., 2016. Antibodies to influenza A viruses in wintering snow geese (Chen caerulescens) in Texas. Avian Dis., 60: 337-340. https://doi.org/10.1637/11104-042115-RegR

Wu, Z.Q., Zhang, Y., Zhao, N., Yu, Z., Pan, H., Chan, T.C., Zhang, Z.R. and Liu, S.L., 2017. Comparative epidemiology of human fatal infections with novel, high (H5N6 and H5N1) and low (H7N9 and H9N2) pathogenicity avian influenza A viruses. Int. J. environ. Res. Publ. Hlth., 14: 263. https://doi. org/10.3390/ijerph 14030263

Xu, X., Subbarao, K., Cox, N.J. and Guo, Y., 1999. Genetic characterization of the pathogenic influenza A/Goose/Guangdong/1/96 (H5N1) virus: Similarity of its hemagglutinin gene to those of H5N1 viruses from the 1997 outbreaks in Hong Kong. Virology, 261: 15-19. https://doi.org/10.1006/viro.1999.9820 